\title{
The Effect of Leverage, Dividend Policy, and Relational Capital on Corporate Performance
}

\author{
Ngadiman \\ Tarumanagara University, \\ Jl. Letjen S. Parman No. 1 Jakarta Barat 11440, Indonesia. \\ E-mail: ngadiman@feuntar.ac.id
}

The purpose of this research is to obtain empirical evidence about the relationship between the effects of leverage, dividend policy, and relational capital on corporate performance of the manufacturing companies listed in the Indonesia Stock Exchange over the period of 2016-2018. This is a quantitative study used secondary data of 117 companies listed on the Indonesian Stock Exchange (IDX) cover period of two years (2016-2018). The study made use of ex-post facto research design. Purposive sampling method employed for selecting data of sample to obtain sample of 117 companies and the unit analyze are 39. Data collection method used in this research is documentation. Methods of data analysis used descriptive statistical analysis and regression moderation with the test of absolute difference value. The data was analyzed using multiple regressions. Three formulated research hypotheses were achieved after tested. The findings from this study show that all the independent variables have effects on corporate performance (ROA) simultaneously (F-test). The t-test results showed that leverage (DAR), which is measured by a debt-to-asset ratio and dividend policy (DPR) which is proxies by a dividend payout ratio have significant effect on corporate performance, while relational capital (RCE) in this study was measured by relational capital efficiency has no significant effect on corporate performance (ROA).

Key words: corporate performance; leverage; dividend Policy; relational Capital.

JEL Classification: JEL: G21; M41.

DOI: $10.17323 / 1813-8691-2020-24-2-295-310$

For citation: Ngadiman. The Effect of Leverage, Dividend Policy, and Relational Capital on Corporate Performance. HSE Economic Journal. 2020; 24(2): 295-310.

Ngadiman - Lecturer at Department of Accounting, Faculty of Economy.

The article was received: 1.06.2020/The article is accepted for publication: 15.06.2020. 


\section{Introduction}

Corporate Performance or also known as company performance is an output produced by a company based on its ability to manage funds and resources available to add value to the company [Costa et al., 2018; Masa'deh et al., 2013]. Besides, performance is an important value for the company and management because it is the result of a process chain that sacrifices business resources including the human and financial resources of the company. Management will always be required to be creative and critical as an effort to improve the performance of their companies by the ever-expanding business world, it is important for management to be able to take advantage of every opportunity that exists as an effort to improve their performance [Galema et al., 2012; Martinez, 2005; Ciora, Robu, 2010].

Corporate performance is a very important benchmark for companies and investors. For companies, performance is closely related to effectiveness and efficiency where effectiveness is a measurement of performance in achieving goals while efficiency is the performance of management in the use of business resources [Costa et al., 2018; Daraban, 2016]. Improved company performance can be seen from the company's incessant activities to generate maximum profits; the amount of profits obtained varies according to company size. The greater potential to manage the investment in business resources is held by companies with a larger size where the management of these investments must provide as much value as possible for investors [Kristianti, 2018]. Therefore, the company's performance is a barometer that measures the level of success or achievement of the company and is used by investors as a basis for making decisions to invest funds [Munteanu et al., 2012].

Performance can motivate investors to invest their funds in particular companies. One example can be illustrated by the performance of the LQ45 stock market index on Indonesia's stock exchange (IDX). The rebalancing of the BEI stock at the end of July 2019 and changes in the weight of the stock caused pressure on stock prices. One of them happened to PT Unilever Indonesia Tbk whose weight decreased from $15.01 \%$ to only $14.24 \%$. The decline for a week in stock prices followed the reduction in weight to $4.58 \%$ to the level, measured in Indonesian rupiahs, around IDR 43,200 (source: BEI historical stock summary). This decrease is fundamentally the opposite shown in the financial statements of the second quarter of 2019, where Unilever still recorded an increase in revenue of $8.2 \%$ to IDR 21.45 trillion. Its profit also increased by $5.12 \%$ to IDR 3.69 trillion (source: second quarter interim financial statements from the IDX). This decrease is fundamentally the opposite shown in the financial statements of the second quarter of 2019, where Unilever still recorded an increase in revenue of 8.2\% to IDR 21.45 trillion. Therefore, investors must take into account the company's performance to evaluate and analyze the profitability and liquidity of the company's previous and current periods by measuring the company's financial performance.

One of the variables that are considered by investors in assessing performance is the company's capital structure. Leverage is also one of the factors that affect a company's performance. Financial leverage is the use of sources of funds that have a fixed burden by assuming that it will provide additional benefits greater than the fixed burden so that it will increase the profits available to shareholders [Sartono, 2008, p. 263]. Companies with high levels of leverage should focus more on improving the quality of their financial performance [Zeitun, Saleh, 2015]. Anderson et al. (cited in [Zeitun, Saleh, 2015]) also suggested that there is a positive relationship between leverage and corporate performance because financial debt places a burden on managers 
to maximize company value. However, in a study conducted by Zeitun and Saleh (2015) found that leverage has a negative and significant relationship to Company Performance, which means the higher the leverage of a company, the lower the Company Performance.

In addition to balancing corporate funding sources, intangible assets such as knowledge to improve competitive ability can improve company performance. Knowledge and skills in running business processes become one of the important components for the company. Therefore, companies are encouraged to manage intellectual capital if they want to achieve a competitive advantage.

Based on the book by Ulum (2017), intellectual capital is intellectual material, knowledge, experience, intellectual property, information that can be used to create value. Competitive advantage can be achieved in various ways such as the use of qualified technology, structured organizational design, and effective, efficient, and economical use of resources. Companies that invest their funds in information resources and technology will tend to excel and last in the long run. Utilization of intangible assets can increase the potential of a company's performance so that it attracts the attention of investors.

Unicorn companies are examples of companies that optimize intellectual capital so they have good performance values in the eyes of investors so they get a lot of investment. Based on empirical test results by Nawaz \& Haniffa (2017) and also Soetanto \& Pei (2018), intellectual capital has a significant effect on corporate performance. But these results are not in line with the results of Buallay's research (2019) which states that intellectual capital does not affect performance. One component of intellectual capital is relational capital, which is calculated using the Relational Capital Efficiency (RCE) proxy.

Relational Capital reflects the value associated with business entities created through the relationship between the organization and its constituents [Tiwari, Vidyarthi, 2018]. Relational Capital can be interpreted as the company's ability to maintain relationships between customers, suppliers, shareholders, and the government. Relationship quality and the ability to create new customers are key factors for a company's success [Anam et al., 2012].

The amount of cash dividend distribution also affects the level of company performance. Companies that announce dividends are a good sign because only companies with good performance can send signals to the market using dividends [Muchtar, 2018]. With the increase in dividends paid, the company's performance has improved and is more attractive to investors.

Based on IFRS Edition Intermediate Accounting book by Kieso, Weygandt \& Warfield (2018), the dividend is a distribution given by the company to shareholders proportionally based on share ownership. Previous research concluded that dividend policy had a significant positive effect on corporate performance [Hafeez, Shahbaz, Iftikhar, Butt, 2018]. This result is not in line with research which states that dividend policy has a significant negative effect on performance [Rajverma, Misra, Mohapatra, Chandra, 2019; Khan, Nadeem, Islam, Salaman, Gill, 2016].

\section{Literature Review}

According to Siro (2013), capital structure is the composition or structure of a company's liabilities. The company funds its assets and resources with various combinations of equity and liquidity. The capital structure can be explained as a mix of funding chosen by the company to finance the company's operations and growth by using a variety of sources of funds [Kristianti, 2018]. 
An optimal capital structure is a capital structure that can maximize company value. Source of financing sourced from liabilities raises costs that are easily identified, namely interest costs. Meanwhile, sources of financing originating from equity create implicit and opportunistic costs.

According to the trade-off theory, sources of financing originating from liabilities give rise to obligations arising from interest expenses. This affects the tax burden that must be borne by the company. The higher the amount of interest expense that must be paid, the greater the amount of tax deduction so that the company will pay the tax payable in a lower amount. However, increasing the proportion of debt will increase the risk of bankruptcy. Companies can choose alternative financing in the form of debt, but the decision will affect cash flow, especially on the company's flexibility in responding to the financial opportunity that arises in the future.

Signal theory explains that managers tend to be related to dividend stability and also the market has a good response to stable dividend policy. Therefore, by paying dividends, the information is released to the market as a good signal and price volatility is reduced so that it affects stock prices. It can be said that information is important to reveal whether dividend signals should be sent, and their effects on company prices and performance.

This theory is one that underlies the distribution of dividends in a company. As explained above, this theory explains that the distribution of dividends gives a sign or shows that the company's performance is good so that it can provide benefits to its investors. That way, investors will be interested in investing in the company to provide funds for the company to increase business growth, or in this case can be said as the company's performance. Besides, the distribution of dividends is also said to affect the stock price, commonly called the value of the company, which indirectly affects the financial performance of the company.

Resource-Based View Theory (RBT) states the company as a collection of resources and capabilities in managing the company's resources. Company resources are heterogeneous, not homogeneous, productive services available come from company resources that provide a unique character for each company. RBT explains the resources owned by the company and how companies can develop competitive advantages from those resources.

RBT assumes that a company's competitive advantage can be obtained from the company's ability to manage and utilize the right combination of resources. These resources can be either tangible or intangible and represent the input in the company's production process, namely capital, equipment, skills from employees, patents, financing, and talented managers. Therefore, companies that manage intellectual capital optimally can create a competitive advantage for companies in competing with competitors and create value added that is beneficial to improve company performance.

\section{Research Hypothesis}

\section{Effect of Leverage on Corporate Performance}

The Leverage Theory explains that financial policy or so-called funding policy is to regulate the balance of sources of company capital to optimize Corporate Performance [Anthonie et al., 2018]. The use of capital from debt sources has benefits and losses. Capital benefits from debt are in the reduction of taxes and the discipline of managers. Meanwhile, the loss of loan capital is the cost of agency and bankruptcy costs. 
Leverage affects the level of profitability of the company. This happens because decisions related to leverage will have an impact on operational activities carried out by the company. The better the performance of the company, the return that will be obtained by investors will increase. With the increasingly competitive competition, financial managers are looking for alternative funding that can minimize the cost of capital. The company's ability to face risks and carry out operational activities can be reflected in its financial performance.

Optimal leverage management will have a positive impact on corporate performance. The optimal capital structure is the right comparison of capital sources between debt and equity. By using a Debt-to-Asset Ratio proxy to measure leverage, the author formulates the hypothesis as follows: $\mathrm{H}_{1}$ : Leverage has a significant impact on Corporate Performance.

\section{Effect of Intellectual Capital on Corporate Performance}

Intellectual Capital can be interpreted as anything related to knowledge, wealth creation, and intangibles according to Vishnu \& Gupta (2014). Ghosh \& Mondal (2009) in [Soetanto, Pei, 2018] stated that intellectual capital is an added value that does not appear in financial statements but if managed properly, will create a competitive advantage for the company over time. In this study, the definition of intellectual capital is all knowledge that can be used to create wealth and added value as a competitive advantage in achieving company goals.

Based on Resource Based View theory, the company's resources can provide a competitive advantage if managed effectively. Resources can be defined as anything that impacts both strengths and weaknesses for the company.

Based on the description above, intellectual capital is categorized as an intangible company asset that does not appear on the financial statements so that it is considered to be trivial. Yet with the development of knowledge and technology, the management of intangible assets is very influential on the value of a company. That way the relational capital proxied by Relational Capital Efficiency (RCE) should have an influence on the company's financial performance.

In the age of digitalization and technological development, the company's need for the ability and skills to process information has also increased. Resource management also changes and creates new methods and innovations that are more effective and efficient. Human resources that were once considered as a burden of income deduction can now be considered as capital or assets of a company which is considered to create added value for the company. The ability, knowledge, and methods that are considered to be able to increase income for the company by maintaining good relationships with customers are called relational capital. Based on the description above, the hypothesis can be formulated as follows: $\mathbf{H}_{2}$ : Relational Capital has a significant impact on Corporate Performance.

\section{Effect of Dividend Policy on Corporate Performance}

Dividend policy is the policy of each company regarding the distribution of dividends to its shareholders. In this study, dividend policy is measured using the Dividend Payout Ratio (DPR) ratio. The DPR is calculated by measuring the ratio of net income distributed to shareholders as cash dividends and retained as retained earnings. Dividend policy is considered to affect company profitability. That is because the distribution of dividends can attract investors 
to invest capital in companies to increase resources for the company. These resources can be used and managed to increase the income of the company.

Signalling theory states the distribution of dividends to shareholders can be interpreted as a positive signal to the market that the company has good financial performance so that it has more cash that can be distributed. Based on the signalling theory, the distribution of cash dividends significantly influences corporate performance.

In the company's efforts to increase investor interest in investing and also maintain the trust of shareholders, the company can make efforts such as providing good information signals to the public. The signal can be in the form of distribution of company income which is commonly referred to as dividends.

To summarize statements above, by distributing dividends, the management announces the results of the company's performance which are usually considered good from the financial point of view. Based on these descriptions, the author formulated the hypothesis as follows: $\mathrm{H}_{3}$ : Dividend Policy has a significant impact on Corporate Performance.

Based on the theoretical basis described above, the author makes the following framework of thought:

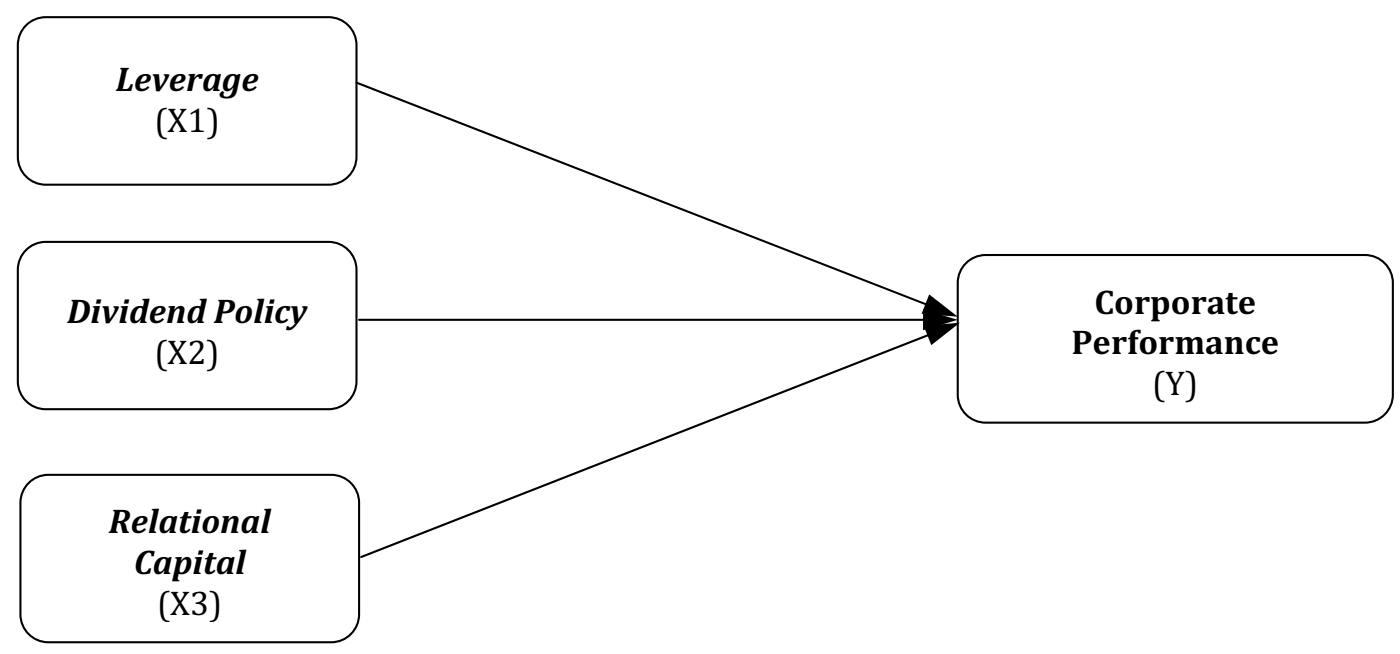

Fig. 1. The Research design Framework

\section{Research Methodology}

The approach used in this study is a quantitative method approach, namely research that starts from theory to then use deductive logic in describing research hypotheses and empirical tests and statistical measurements to obtain research results.

In this study the population taken were all manufacturing companies listed on the Indonesia Stock Exchange, which were 178 companies, the number of which was known through the IDX website. The population is presented as follows: 


\section{Research Subject}

\begin{tabular}{r|r|c}
\hline No & Industry Category & Total Firms \\
\hline 1 & Basic Industry and Chemical Sector & 75 \\
2 & Miscellaneous Industry Sector & 49 \\
3 & Consumer Goods Industry Sector & 54 \\
& Total Manufacturing Industry Company & $\mathbf{1 7 8}$ \\
\hline \hline
\end{tabular}

The sample in this study was selected using the purposive sampling method, so that the sample was selected with certain criteria first. In this study, the sample that met the criteria was 40 manufacturing companies in 2016-2018. Following are the sample criteria used:

\section{Procedure and Results of Selection of Research Samples}

\begin{tabular}{c|l|c}
\hline No & Criteria & Total \\
\hline 1 & $\begin{array}{l}\text { Manufacturing companies listed successively on the Indonesia Stock } \\
\text { Exchange during 2016-2018 }\end{array}$ & 177 \\
2 & Companies with an IPO date in the period 2016-2018 \\
3 & $\begin{array}{l}\text { Companies that do not use the Rupiah currency in the 2016-2018 } \\
\text { Financial Statements }\end{array}$ & \\
4 & $\begin{array}{l}\text { Companies that do not report financial statements in the 2016-2018 } \\
\text { period }\end{array}$ & (28) \\
5 & Companies that did not experience net profit during 2016-2018 \\
6 & Companies that did not distribute cash dividends during 2016-2017 \\
7 & Companies with different reporting periods & $(34)$ \\
\hline \hline
\end{tabular}

This research data collection method is to use the method of literature that is by conducting library studies such as books, journals, and some literature relating to the problems in this study. As well as taking data on the financial statements of manufacturing companies that are on the Indonesia Stock Exchange or referred to as the use of secondary data. 


\section{Operationalization of Variables}

Leverage is calculated using the Debt to Asset Ratio (DAR) method. DAR illustrates the comparison of corporate financing sources derived from debt and equity. The second independent variable is Relational Capital which is measured using the Relational Capital Efficiency (RCE) proxy. RCE calculates the presence or absence of added value provided from intangible assets to the company. The third independent variable is the Dividend Policy or dividend policy that describes the distribution of profits to shareholders using the proxy Dividend Payout Ratio (DPR). And to calculate the dependent variable of this study, Corporate Performance, uses financial ratios such as Return on Assets (ROA) to measure the rate of return on the profitability of company assets and resources. A summary of the table operationalization of variables and the following proxy of research variables is presented in table 3 as follows:

Table 3.

Operationalization of Research Variables

\begin{tabular}{lcc}
\hline \multicolumn{1}{c|}{ Variable } & Size & Scale \\
\hline Leverage & $D A R=\frac{\text { Total Debt }}{\text { Total Asset }}$ & Ratio \\
Value Added & $V A=O P+E C+D+A$ & Ratio \\
Relation Capital & $R C E=\frac{R C}{V A}$ & Ratio \\
Dividend Payout Ratio & RPR $=\frac{\text { Dividend }}{\text { Net Income }}$ \\
Return On Asset & $R O A=\frac{\text { Net Income }}{\text { Total Asset }}$ \\
\hline \hline
\end{tabular}

\section{Data Analysis Method}

In this study, the author used multiple regression analysis. According to Uma Sekaran (2013), multiple regression analysis can be defined as an analysis that explains the relationship between variables and the positive or negative effects that exist from an independent variable on the dependent variable.

Following are the equations of the multiple regression analysis model:

$$
Y=\alpha+\beta_{1} X_{1}+\beta_{2} X_{2}+\beta_{3} X_{3}+\varepsilon .
$$

Explanation: $Y$ - corporate performance; $\alpha$ - constanta; $\beta_{1}-\beta_{3}$ - coefficient regression; $X_{1}-$ leverage; $X_{2}$-dividend policy; $X_{3}$-relational capital; $\varepsilon$ - error (residual value). 


\section{Hypothesis Test Results}

After the research object data is collected, the author conducts a descriptive statistical test with the E-views version 10 program to assess and provide an overview of the characteristics of all company data to be analyzed. By doing a descriptive statistical test, the average value (Mean), minimum value (Min), maximum value (Max), and Standard Deviation (Std) of each independent variable Leverage $\left(X_{1}\right)$, Dividend Policy $\left(X_{2}\right)$, Relational Capital $\left(X_{3}\right)$, and the dependent variable Corporate Performance $(Y)$ will be known.

The descriptive statistical test results presented in Table 4 show the mean value, maximum value, minimum value, and standard deviation based on the total number of sample data (Observations) totalling 117 samples during the study period.

Table 4.

Statistical Test Results

Sample: 20162018

\begin{tabular}{lcccc}
\hline \hline & ROA & LEVERAGE & DPR & RCE \\
\hline \hline Mean & 0.111203 & 0.362836 & 0.500659 & 0.122533 \\
Median & 0.074166 & 0.357166 & 0.373030 & 0.060151 \\
Maximum & 0.920997 & 0.726369 & 5.196196 & 1.072524 \\
Minimum & 0.000782 & 0.131981 & 0.006376 & 0.000000 \\
Std. Dev. & 0.124800 & 0.164780 & 0.596356 & 0.187030 \\
Skewness & 3.343132 & 0.419968 & 4.844880 & 2.931322 \\
Kurtosis & 18.35371 & 2.195200 & 35.32855 & 13.37494 \\
& & & & \\
Jarque-Bera & 1367.157 & 6.596818 & 5552.753 & 692.2989 \\
Probability & 0.000000 & 0.036942 & 0.000000 & 0.000000 \\
Sum & 13.01076 & 42.45179 & 58.57710 & 14.33631 \\
Sum Sq. Dev. & 1.806695 & 3.149668 & 41.25426 & 4.057712 \\
Observations & 117 & 117 & & 117 \\
\hline \hline
\end{tabular}

Leverage has an average value (mean) of 0.362836 and a median value of 0.357166 . While the maximum value of 0.726369 belongs to the Unilever Company in 2017 and the minimum value of 0.131981 which belongs to the Bolt Company in 2016. The standard deviation of the leverage variable is 0.164780 .

Dividend Policy has an average value (mean) of 0.500659 and a median value of 0.373030 . While the maximum value of 5.196196 which belongs to the company Selamat Sempurna in 2018 and the minimum value of 0.006376 which belongs to the company Selamat Sempurna in 2016. The standard deviation of the variable dividend policy is 0.596356 .

Relation capital has an average value (mean) of 0.122533 and a median value of 0.060151 . While the maximum value of 1.072524 belongs to Kino Indonesia in 2018 and the minimum value of 0.000000 belongs to Asahimas Flat Glass, Fajar Surya Wisesa, and Lionmesh Prima. The standard deviation of the variable relation capital is 0.187030 . 
ROA has an average value (mean) of 0.111203 and a median value of 0.074166 . While the maximum value of 0.920997 belongs to the company Merck Tbk. in 2018 and the minimum value of 0,000782 which belongs to the company Asahimas Flat Glass in 2018. The standard deviation of the corporate performance variable (ROA) is 0.124800 .

\section{Results of Multiple Linear Regression Analysis}

In this study, multiple linear regression analysis tests were conducted to determine the effect of Leverage $\left(X_{1}\right)$, Dividend Policy $\left(X_{2}\right)$, and Relational Capital $\left(X_{3}\right)$ on Financial Performance $(Y)$ on manufacturing companies. The data model used is the Fixed Effect Model which is selected based on the results of the data assumptions using the Chow Test and the Hausman Test.

\section{Results of Multiple Linear Regressions}

Table 5.

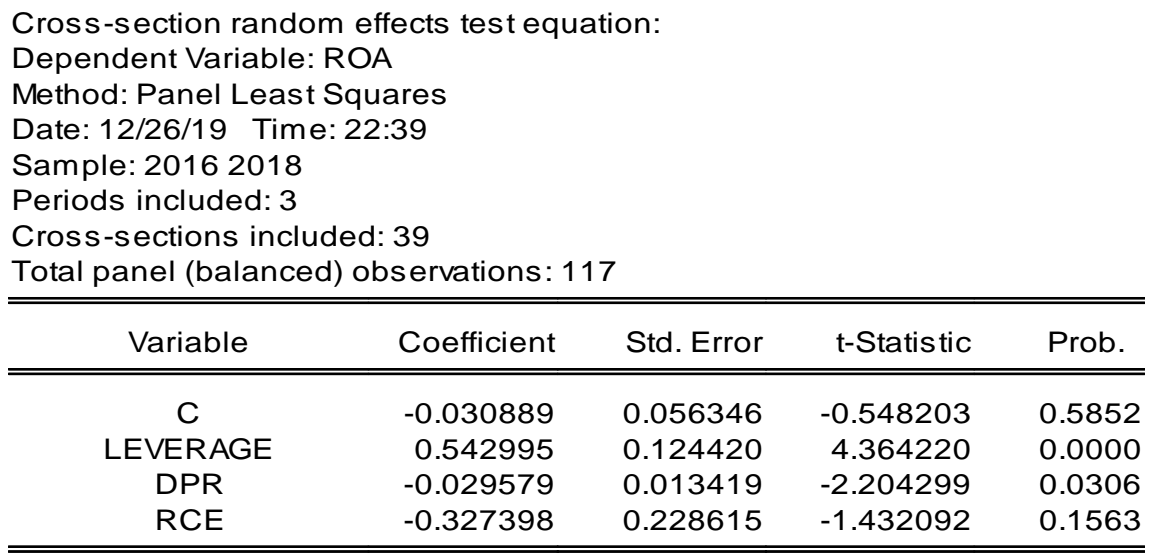

Based on the results of data processing in Table 5, it can be concluded that this research model is as follows:

$$
\begin{gathered}
Y=\alpha+\beta_{1} X_{1}+\beta_{2} X_{2}+\beta_{3} X_{3}+\varepsilon . \\
Y=-0.030889+0.542995 X_{1}-0.029579 X_{2}-0.327398 X_{3}-0.030889+\varepsilon
\end{gathered}
$$

Explanation: $Y$ - corporate performance proxied by $R O A$; $C$ - constant; $X_{1}$ - leverage is proxied by $D A R ; X_{2}$ - relational capital proxied by $R C E ; X_{3}$ - dividend policy proxied by the $D P R ; \varepsilon$ - error.

\section{Simultaneous Test Results}

Simultaneous Test or so-called F-Test with $\alpha=5 \%$ is to determine the effect of Leverage $\left(X_{1}\right)$, Dividend Policy $\left(X_{2}\right)$, and Relational Capital $\left(X_{3}\right)$ on Corporate Performance $(Y)$ together or simultaneously. 
Based on the results of the processed data is showed that the F-static probability value is 0.000000 , so it can be concluded that the panel data regression model is appropriate and suitable for use in this study. Because the F-statistic probability value is 0.000000 , which is smaller than 0.05 , it means that the independent variable has a significant effect on the dependent variable simultaneously.

\section{Results of Partial Test}

T-test or also known as a partial test is a test that examines how the influence of each independent variable individually on the dependent variable. The T-test is done after conducting simultaneous tests and is used to find out whether the panel data regression model is feasible to use, then Partial Test (T-test) with $\alpha=5 \%$ is used to determine the effect of each (partial) independent variable on the dependent variable.

\section{Results of T-test}

Table 6.

\begin{tabular}{|c|c|c|c|c|}
\hline \multicolumn{5}{|c|}{$\begin{array}{l}\text { Cross-section random effects test equatio } \\
\text { Dependent Variable: ROA } \\
\text { Method: Panel Least Squares } \\
\text { Date: } 12 / 26 / 19 \text { Time: } 22: 39 \\
\text { Sample: } 20162018 \\
\text { Periods included: } 3 \\
\text { Cross-sections included: } 39 \\
\text { Total panel (balanced) observations: } 117\end{array}$} \\
\hline C & -0.030889 & 0.056346 & -0.548203 & 0.5852 \\
\hline LEVERAGE & 0.542995 & 0.124420 & 4.364220 & 0.0000 \\
\hline DPR & -0.029579 & 0.013419 & -2.204299 & 0.0306 \\
\hline RCE & -0.327398 & 0.228615 & -1.432092 & 0.1563 \\
\hline
\end{tabular}

Based on the results of the T-test in Table 6, the probability value of the independent variable Leverage $\left(X_{1}\right)$ is 0.0000 , which means the Leverage variable $\left(X_{1}\right)$ has a significance value of 0.0000 . Because the significance value of the independent variable is smaller than 0.05 , it can be concluded that Leverage $\left(X_{1}\right)$ has a positive and significant effect on Corporate Performance $(Y)$.

The probability value of the independent variable Dividend Policy $\left(X_{2}\right)$ is 0.0306 , which means the Relational Capital variable $\left(X_{2}\right)$ has a significance value of 0.0306 . Because the significance value of the independent variable is smaller than 0.05 , it can be concluded that the Dividend Policy $\left(X_{2}\right)$ has a negative influence and significantly influences the Corporate Performance $(Y)$.

The probability value of the independent variable Relational Capital $\left(X_{3}\right)$ is 0.1563 , which means the Relational Capital $\left(X_{3}\right)$ variable has a significance value of 0.1563 . Because the 
significance value of the independent variable is greater than 0.05 , it can be concluded that Relational Capital $\left(X_{3}\right)$ has a negative and not significant effect on Corporate Performance $(Y)$.

\section{Multiple Determination Coefficient Test}

The Multiple Determination Coefficient Test $\left(R_{2}\right)$ is carried out to find out how much the variation of the independent variables, namely Leverage $\left(X_{1}\right)$, Dividend Policy $\left(X_{2}\right)$, and Relational Capital $\left(X_{3}\right)$ in explaining their influence on the dependent variable, namely Corporate Performance $(Y)$.

Table 7.

Results of Multiple Determination Coefficient Test

\begin{tabular}{lrlr}
\hline \hline \multicolumn{4}{c}{ Effects Specification } \\
\hline \hline Cross-section fixed (dum my variables) & & \\
\hline \hline & 0.824841 & Mean dependent var & 0.111203 \\
R-squared & 0.729087 & S.D. dependent var & 0.124800 \\
Adjusted R-squared & 0.064957 & Akaike info criterion & -2.356908 \\
S.E. of regression & 0.316460 & Schwarz criterion & -1.365358 \\
Sum squared resid & 179.8791 & Hannan-Quinn criter. & -1.954351 \\
Log likelihood & 8.614182 & Durbin-Watson stat & 2.510348 \\
F-statistic & 0.000000 & & \\
Prob(F-statistic) & & & \\
\hline \hline
\end{tabular}

Based on the results presented in Table 7, it can be seen that the Adjusted R-squared result is 0.729087 , which means that the dependent variable can be explained by independent variables as much as $72.91 \%$. In other words, Leverage $\left(X_{1}\right)$, Dividend Policy $\left(X_{2}\right)$, and Relational Capital $\left(X_{3}\right)$ can explain their combined effect on Corporate Performance $(Y)$ as much as $72.91 \%$. Taking into account the aforementioned proxies, it can be concluded that the ability of Leverage $\left(X_{1}\right)$, Intellectual Capital $\left(X_{2}\right)$, and Dividend Policy $\left(X_{3}\right)$ in predicting and influencing Corporate Performance $(Y)$ is quite high, amounting to $72.91 \%$, while factors outside the independent variables in this study that affect Corporate Performance $(Y)$ is only $27.09 \%$.

\section{Discussion}

Sukasa, Suhadak \& Hidayat (2017) explain that leverage is a comparison of a company's long-term funding from debt and equity. The use of optimal financing can positively affect the performance of the company. This opinion is based on the Trade-off theory which states that there is an Optimal Leverage point which is the result of a reciprocal relationship between the benefits of tax savings caused by the use of debt as a source of funding and the risk of bankruptcy resulting from high debt thereby suppressing the use of property funds to finance corporate funding. 
Based on the results of hypothesis testing in Table 3 , the probability value of the Leverage variable is 0.0000 which is smaller than 0.05 , thus indicating that the Leverage variable significantly influences the dependent variable in this study, namely Corporate Performance. With a positive coefficient, leverage shows a positive effect on Corporate Performance. Based on the results of the study, leverage is one of the factors that drive the company's profitability. This is shown from the reciprocal relationship between the capital structures proxied by DAR, directly proportional to the company's performance. If the DAR value gets higher, the company's performance will also increase. The DAR value will increase if funding from debt is higher.

Based on the results of the hypothesis test presented in Table 6 the results are in accordance with the alternative hypothesis of the author in which leverage has a significant effect on Corporate Performance. The results of this study are also supported by research by Anderson et al. (2003) in [Zeitun, Saleh, 2015].

These results are in line with the expectations of the author, and also after being compared with previous theories and studies, it can be concluded that leverage that is proxied by $D A R$ has a positive and significant effect on corporate performance.

\section{Effect of Dividend Policy $\left(X_{2}\right)$ on Corporate Performance $(Y)$}

The distribution of dividends is considered as a good signal to the public that the company's performance is good, so based on signalling theory, the distribution of dividends is considered as a factor that affects the stock price and also the performance of the company.

The results of the study presented in table 6 show a probability value of 0.0306 which indicates that the independent variable Dividend Policy significantly influences the dependent variable Corporate Performance because the probability value is smaller than 0.05 . The results of this test are in accordance with the alternative research hypothesis, where the Dividend Policy that uses the Dividend Payout Ratio proxy has a significant effect on the Corporate Performance variable. The results of this study are in line with the results of research by Rajverma, Misra, Mohapatra \& Chandra (2019) and also research by Khan, Nadeem, Islam, Salman \& Gill (2016).

The coefficient value of the Dividend Policy variable based on the summary of the results of hypothesis testing in table 6 is -0.029579 . This significant negative effect is caused by the decrease in retained earnings when the company distributes dividends to shareholders thereby reducing the company's internal income [Khan et al., 2016]. In other words, the distribution of dividends to shareholders will reduce the amount of cash the company or so-called cash crunch will have an impact on reducing the level of profitability of the company. In short, cash is used by companies to fund day-to-day operations for their expenditure cycles in order to generate revenue. But the cash is reduced because it is used as a distribution of returns to shareholders so that it will indirectly hamper operational or company expansion plans.

\section{Effect of Relational Capital $\left(X_{3}\right)$ on Corporate Performance $(Y)$}

Relational Capital in this study uses the Proportion of Relational Capital Efficiency proposed by Ulum (2014) which is a component of the development of Value Added Intellectual Coefficient previously triggered by Pulic (1998).

Resource-Based Theory explains that intellectual capital is one of the intangible assets which, if managed and utilized properly, can provide a competitive advantage for the company so that the competitive advantage can improve the company's performance in generating income. 
Based on the summary of the results of the study in table 6, the probability value of the Relational Capital variable is 0.1563 which is greater than 0.05 so that the Relational Capital variable does not show a significant effect on the dependent variable in this study, namely Corporate Performance. With a coefficient value of -0.327398 , it indicates that the Relational Capital variable tends to be negative or can be interpreted to have an inverse relationship with the variable Corporate Performance.

The results of the study are not in accordance with the hypotheses of researchers because Relational Capital does not significantly influence Corporate Performance. That way, this research is not in line with the results of research by Soetanto \& Pei (2018) and also the research of Tiwari \& Vidyarthi (2018).

The results of the research that are not in accordance with the researcher's hypothesis can be caused by internal company factors such as the lack of optimal utilization of resources, the company's low appreciation of employee skills, and also the decrease in the amount of use of human labor in manufacturing companies because they are replaced with modern technology that uses systems digitally. Although the results of this study are not in accordance with the author's expectations, this assumption is supported by the results of research by Buallay (2019).

\section{Conclusion}

Based on the discussion of data analysis described, the variables used in this study indicate that the research model is appropriate and feasible to use because the probability value of $\mathrm{F}$ is 0.000000 , which means it is smaller than 0.05 so the results of the study indicate that the independent variable has a significant effect on the dependent variable when tested simultaneously or together. From the partial test results, it can be concluded that the leverage in this study is measured by a debt-to-asset ratio proven to have a significant effect on corporate performance. The dividend policy which is proxies by a dividend payout ratio also significantly influences corporate performance. While the relational capital in this study was measured by relational capital efficiency and it has proved no effect on company performance. This can be due to the ineffective effect of the use of marketing companies in establishing relationships with their customers. In addition, it can also be concluded that the ability of independent variables in this study, such as Leverage $\left(X_{1}\right)$, Intellectual Capital $\left(X_{2}\right)$, and Dividend Policy $\left(X_{3}\right)$ in predicting and influencing Corporate Performance $(Y)$ is quite high, amounting to $72.91 \%$.

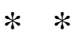

\section{References}

Brigham H. (2016) Dasar-Dasar Manajemen Keuangan. Edisi Kedua. Jakarta: Salemba Empat. Buallay A. (2019) Intellectual Capital and Performance of Islamic and Conventional Banking: Empirical Evidence from Gulf Cooperative Council Countries. Journal of Management Development, 38, 7, pp. 518537. Available at: https://doi.org/10.1108/JMD-01-2019-0020

Ciora C., Robu V. (2010) Measuring Performance, Value Creation and Value-based Management in the Context of Competitiveness and Globalization. Annals of Computational Economics, 2, 38, pp. 1-8. 
Costa C., Da M.X., Laksamana A., Rahayu M. (2018) The Relation between Institutional Ownerships, Debt Policy, Dividend Policy And Company Performance In Terms Of Clarifying Agency Conflict Mechanism: Case Study At Manufacturing Companies Listed At The Indonesian Stock Exchange. International Journal of Scientific Research and Management, 6, 7, pp. 503-521. Available at: https://doi.org/10.18535/ijsrm/ v6i7.em02

Daraban M. (2016) An Empirical View on Value Theory and Value-based Management. CBU International Conference Proceedings, 4. 10.12955/cbup.v4.740.

Esthirahayu D.P. (2014) Pengaruh Rasio Likuiditas, Rasio Leverage Dan Rasio Aktivitas Terhadap Kinerja Keuangan Perusahaan (Studi pada Perusahaan Food and Beverage yang Listing di Bursa Efek Indonesia Tahun 2010-2012). Jurnal Administrasi Bisnis, 8, 1, pp. 1-9.

Galema R.; Lensink R.; Mersland R. (2012) Do Powerful CEOs Determine Microfinance Performance? Journal of Management Studies, 49, pp. 718-742.

Hafeez M.M., Shahbaz S., Iftikhar I., Butt H. (2018) Impact of Dividend Policy on Firm Performance: Evidence from the Manufacturing firms in Pakistan. International Journal of Advance Study and Research Work, 1, 4, pp. 1-5. Available at: https://doi.org/10.5281/zenodo.1312180

Isbanah Y. (2015) Pengaruh Esop, Leverage, and Ukuran Perusahaan Terhadap Kinerja Keuangan Perusahaan Di Bursa Efek Indonesia. Jurnal Riset Ekonomi Dan Manajemen, 15, 1, pp. 28-41. Available at: https://doi.org/10.17970/jrem.15.150103.id

Khan M.N., Nadeem B., Islam F., Salman M. (2016) Impact of Dividend Policy on Firm Performance: An Empirical Evidence From Pakistan Stock Exchange. American Journal of Economics, Finance and Management, 2, 4, pp. 28-34.

Kristianti I.P. (2018) Analisis Pengaruh Struktur Modal. Akuntansi Dewantara, 2, 1, pp. 56-68. Available at: https://doi.org/10.29230/ad.v2i1.2222

Liaqat I., Saddique S., Bagh T., Atif Khan M., Naseer M.M., Khan M.A. (2017) Capital Structure as Driving Force of Financial Performance: Case of Energy and Fuel Sector of Pakistan. International Journal of Accounting and Financial Reporting, 7, 1. Available at: https://doi.org/10.5296/ijafr.v7i1.7722

Masa'deh Ra'Ed, Tayeh M., Jarrah I., Tarhini A. (2015) Accounting vs. Market-based Measures of Firm Performance Related to Information Technology Investments. International Review of Social Sciences and Humanities, 9, pp. 129-145.

Munteanu V., Danaita D., Hurbean L., Bergler A. (2012) The Value-Based Management Approach: From The Shareholder Value To The Stakeholder Value. Proceedings of $6^{\text {th }}$ International Management Conference «Approaches In Organisational Management», 15-16 November 2012, Bucharest, Romania, pp. 39-44.

Martinez V. (2005) What Is the Value of Using Performance Management Systems? Government by Design, Centre for Business Performance, Cranfield School of Management.

Musah A. (2018) The Impact of Capital Structure on Profitability of Commercial Banks in Ghana. Asian Journal of Economic Modelling, 6, 1, pp. 21-36. Available at: https://doi.org/10.18488/journal. 8.2018.61.21.36

Nainggolan I. P. M., Pratiwi M.W. (2017) Analisis Faktor-Faktor Yang Mempengaruhi Kinerja Keuangan Perusahaan. Media Ekonomi Dan Manajemen, 32, 1. Available at: https://doi.org/10.24856/mem.v32i1.465 Nurlaela S., Mursito B., Kustiyah E., Istiqomah I., Hartono S. (2019) Asset Turnover, Capital Structure and Financial Performance Consumption Industry Company in Indonesia Stock Exchange. International Journal of Economics and Financial Issues, 9, 3, pp. 297-301. Available at: https://doi.org/10.32479/ijefi.8185

Pramesti D., Wijayanti A., Nurlaela S. (2016) Pengaruh Rasio Likuiditas, Leverage, Aktivitas Dan Firm Size Terhadap Profitabilitas Perusahaan Sub Sektor Otomotif Dan Komponen Di Bursa Efek Indonesia. Seminar Nasional IENACO, pp. 810-817. Retrieved from https://publikasiilmiah.ums.ac.id/handle/11617/7162

Rajverma A.K., Misra A.K., Mohapatra S., Chandra A. (2019) Impact of Ownership Structure and Dividend on Firm Performance and Firm Risk. Managerial Finance, 45, 8, pp. 1041-1061. Available at: https://doi.org/10.1108/MF-09-2018-0443

Ramadan Z.S., Ramadan I.Z. (2015) Capital Structure and Firm's Performance of Jordanian Manufacturing Sector. International Journal of Economics and Finance, 7, 6, pp. 279-284. Available at: https://doi.org/ 10.5539/ijef.v7n6p279 
Sekaran U., Bougie R. (2013) Research Methods for Business: A Skill Building Approach. Edisi Lima. New York: John Wiley \& Sons, Inc.

Soetanto T., Liem P.F. (2019) Intellectual Capital in Indonesia: Dynamic Panel Approach. Journal of Asia Business Studies, 13, 2, pp. 240-262. Available at: https://doi.org/10.1108/JABS-02-2018-0059.

Sukasa L., Suhadak Hidayat R.R. (2017) The Influence Of Corporate Governance And Capital Structure (Studies on Companies that were Rated in CGPI Listed on The Indonesia Stock Exchange For 2011-2015). Jurnal Administrasi Bisnis (JAB), 42, 1, pp. 66-74.

Tiwari R., Vidyarthi H. (2018) Intellectual Capital and Corporate Performance: A Case of Indian Banks. Journal of Accounting in Emerging Economies, 8, 1, pp. 84-105. Available at: https://doi.org/10.1108/JAEE07-2016-0067

Ulum I., Ghozali I., Malang U.M., Semarang U.D. (2014) Konstruksi Model Pengukuran Kinerja Dan. Jurnal Akuntansi Multiparadigma (JAMAL), 5, 3, pp. 380-392.

Ulum I. (2016) Intellectual Capital: Model Pengukuran, Framework Pengungkapan \& Kinerja Organisasi. Malang : UMM Press.

Vincent F., Djabir A., Elli Silviyana H.M, Fransiscus K. (2018) Pengaruh Fixed Assets Turnover, Debt To Total Assets Ratio Dan Current Ratio Terhadap Return on Assets Pada Perusahaan Sub Sektor Crude Petrolum Dan Natural Production (Minyak Mentah Dan Gas Bumi) Yang Terdaftar Di Bursa Efek Indonesia Periode 2012-2014. Jurnal Riset Manajemen Dan Bisnis, 3, 2, pp. 71-78.

Vishnu S., Gupta V. (2014) Intellectual Capital and Performance of Pharmaceutical Firms in India. Journal of Intellectual Capital, 15, 10.1108/JIC-04-2013-0049.

Widyastuti M. (2019) Analysis of Liquidity, Activity, Leverage, Financial Performance And Company Value in Food and Beverage Companies Listed on The Indonesia Stock Exchange. International Journal of Economics and Management Studies, 6, 5, pp. 52-58. Available at: https://doi.org/10.14445/23939125/ ijems-v6i5p109

Zakaria G.A., Djoko H. (2016) Pengaruh Intellectual Capital Terhadap Kinerja Perusahaan (Studi Kasus Pada Perusahaan Industri Barang Konsumsi yang Tercatat di BEI Tahun 2012-2014). (Ic).

Zeitun R., Saleh A.S. (2015) Dynamic Performance, Financial Leverage and Financial Crisis: Evidence from GCC Countries. EuroMed Journal of Business, 10, 2, pp. 147-162. Available at: https://doi.org/10.1108/ EMJB-08-2014-0022. 